The power of sophistication: How service design cues help in service failures

Mellina da Silva Terres ${ }^{1}$, Márcia Maurer Herter², Diego Costa Pinto3, José A. Mazzon ${ }^{4}$

1 Federal University of Health Sciences of Porto Alegre (UFCSPA), Porto Alegre, Brazil

2 Universidade Europeia (UE), Lisbon, Portugal

3 NOVA Information Management School (NOVA IMS), Universidade Nova de Lisboa, Lisbon, Portugal

4 University of S ao Paulo (USP), Sao Paulo, Brazil

This is the peer reviewed version of the following article: Terres, M. D. S., Herter, M. M., Pinto, D. C., \& Mazzon, J. A. (2020). The power of sophistication: How service design cues help in service failures. Journal of Consumer Behaviour. [Advanced online publication on $20 \mathrm{March}$, 2020]. https://doi.org/10.1002/cb.1816

This article may be used for non-commercial purposes in accordance with Wiley Terms and Conditions for Use of Self-Archived Versions."

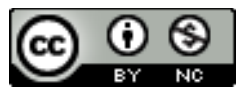

This work is licensed under a Creative Commons Attribution-NonCommercial 4.0 International License. 


\title{
The Power of Sophistication: How Service Design Cues Help in Service Failures
}

\begin{abstract}
By analyzing three experimental studies, this research tests how and when sophisticated service environment designs (compared to modest service designs) can minimize consumers' negative emotions and increase repurchase intentions after a failure. Drawing on part-list cueing literature, this research proposes that when a service failure occurs in a sophisticated (vs. modest) environment, consumers will rely on the sophisticated style of design as cues for service quality. We argue that sophisticated (vs. modest) service designs work as strong cues for quality that restrict the retrieval of negative information by consumers and can minimize the negative impacts of service failure, reducing consumers' negative emotions and increasing repurchase intentions. We further advance our theorizing by showing how choice failure consequences (i.e., the risk or consequence related to the service choice) moderate the effects via associative pathways of retrieval. The findings contribute to theory and practice by revealing how service designs can serve as cues to mitigate adverse consequences of service failure.
\end{abstract}

Keywords: service design, service environment, service failure, part-list cueing, negative emotions, repurchase intentions. 


\section{Introduction}

Companies use service environment designs as cues to build positive sensory impressions in consumers in the hopes of improving customer experience and outcomes (Berry et al., 2002; Bitner, 1992; Chang, 2016; Dean, 2014; DiPietro and Campbell, 2014; Durna et al., 2015; Kotler, 1973; Sweeney et al., 2016; Walsh et al., 2011). Service providers using sophisticated designs are known for creating incredible customer experiences and building an emotional connection with consumers to improve loyalty. According to Forbes (2018), brands like Ritz-Carlton use service designs to signal consumers their sophistication and to assure their service quality cues match the brand's reputation. For Harvard Business Review (2016), managers of companies oriented towards sophistication need to use any business opportunity to deliver high-quality cues (e.g., a luxurious service design experience) to be knowledgeable enough to go beyond the standard. The extant literature has also highlighted the positive impact of service environment designs (e.g., ambient, design, and social factors) on consumer outcomes such as perceived quality, emotional response, and repurchase intentions (Bitner, 1990; Hooper et al., 2013; Kearney et al., 2013; Shostack, 1977; Sweeney at al., 2016; Westbrook and Oliver, 1991; Kumar and Kim, 2014; Robert and John, 1982).

Nevertheless, while the body of research suggests the important role played by service environment designs on consumer emotions and behavioral intentions (Pullman and Gross, 2004; Petzer et al., 2012; Sengupta et al., 2015), insights into whether service designs can influence consumers' responses after service failures remain unknown. Service failures occur when providers fail to meet consumers' expectations (Zeithaml et al., 2011), generating adverse effects on consumer behavior (e.g., Bonifield and Cole, 2007; Harrison-Walker, 2012; Reynolds and Harris, 2009). From a practical standpoint, service failures cost 
businesses around $\$ 62$ billion per year due to the loss of disappointed clientele (Forbes, 2016). Thus, understanding how service designs can work as cues to influence consumers' responses to service failures is a key factor for marketing theory and practice.

In order to fill this gap, this research tests how and when sophisticated service environment designs (compared to modest service designs) can minimize consumers' negative emotions and increase repurchase intentions after a failure. Drawing on part-list cueing literature (e.g., Garcia-Marques and Hamilton, 1996; Lindsey and Krishnan, 2007), this research proposes that when a service failure occurs in a sophisticated (vs. modest) environment, consumers will rely on the sophisticated style of design as cues for service quality to decide whether to repurchase or not from the same service provider. We argue that sophisticated (vs. modest) service designs work as strong cues for quality that restrict the retrieval of negative information by consumers and can minimize the negative impacts of service failure, reducing consumers' negative emotions and increasing repurchase intentions. That is because service environment designs generate positive expectations of service quality on consumers (Zeithaml et al., 2011) helping customers regulate their emotional response by reinterpreting the negative event positively (Balaji et al., 2017). We further advance our theorizing by showing how choice failure consequences (i.e., the risk or consequence related to the service choice) moderate the effects via associative pathways of retrieval (GarciaMarques and Hamilton, 1996).

By doing so, this research makes three contributions to the literature. First, it advances the understanding of consumer reactions to service failures by showing how sophisticated (vs. modest) service environment designs help to shape consumers' repurchase intentions after a service failure. In doing so, this research goes beyond previous research in service systems (e.g., Santos-Vijande et al., 2013) to reveal the important role of service environment designs in the post-failure recovery. Second, it provides evidence for the mediating role of negative 
emotions, suggesting that sophisticated (vs. modest) service designs work as quality cues that restrict the retrieval of negative information by consumers and can minimize the negative impacts of service failure. In doing so, this research contributes to the more recent stream of research on service environment designs (Balaji et al., 2017; Choi and Choi, 2014, Patrício et al., 2018) aimed at uncovering the emotional mechanisms underlying consumer reactions to service failure. Third, it broadens the extant understanding of the boundary conditions that affect service failures by introducing the moderating role of choice failure consequences. By doing so, we contribute to the marketing literature on consumer's information retrieval (e.g., Alba and Chattopadhyay, 1985; Lindsey and Krishnan, 2007; Stocchi et al., 2016), uncovering retrieval processes that might explain under which conditions service design cues mitigate negative effects of service failure.

\section{Service Environment Design Cues and Service Failure}

Service environment designs refer to a combination of ambient (e.g., temperature, music, odor), design (e.g., architecture, equipment, furnishing), and social factors (e.g., staff, other customers) (Bitner, 1992). The ambient factor implies background conditions such as air quality (temperature, humidity, and circulation), noise, scent, and cleanliness. The design factor relates to the visual stimuli component in terms of functional cues that includes layout (space arrangement) and comfort and aesthetic cues that include architecture, décor, and furniture. The social factor is the human component of the environment, that is the audience (other customers in the service environment), and service personnel. Consumers' perceptions of social factors also include appearance, behavior, and contact with people in the environment (Baker et al., 1994; Dagger et al., 2013). Extant research has demonstrated the 
relevance of service designs in producing positive customer reactions such as emotions and behavioral intentions (e.g., Baker et al., 1994; Bitner, 1990, 1992; Ellen and Zhang, 2014; Hooper et al., 2013; Kearney et al., 2013; Kotler, 1973).

Consumers evaluate the service designs as "indicators in forming beliefs about service quality and other attributes of the service" (Bitner, 1992, p. 63). The part-list cueing literature (e.g., Garcia-Marques and Hamilton, 1996; Lindsey and Krishnan, 2007) suggests that the information describing a target (service design cues) is encoded and stored in memory in a representation identified with that target (i.e., this service provider has high or low quality). Thus, consumers use service designs as cues of expected service quality (Reimer and Kuehn, 2005), impacting their behavioral intentions (Durna et al., 2015).

In the occurrence of failure, consumers need to deal with the negative service encounter to manage their emotions and reinterpret events positively (Gabbott et al. 2011; Balaji et al., 2017). This research draws from part-list cueing literature (e.g., Garcia-Marques and Hamilton, 1996; Lindsey and Krishnan, 2007) to argue that sophisticated service designs (compared to modest service designs) can signal stronger quality cues to consumers, minimizing the negative effects of service failure. This reaction is because the degree of fit between a retrieval cue (sophisticated design) and the stored memory (associations with high quality) traces as a whole as a clue to some aspect of memory content (e.g., associations between sophistication and better quality). This retrieval process favors expectancy-congruent behaviors (Garrido et al., 2012), which makes consumers overestimate frequency judgments that sophisticated designs and high quality are usually congruent (and much more frequent compared to a given episodic failure event). Thus, consumers will tend to repurchase more from sophisticated (vs. modest) service designs since it signals stronger quality cues (expectancy-congruent behaviors). More formally, we hypothesize that: 
$\mathbf{H}_{1}$ : Sophisticated (vs. modest) service environment designs reduce the dampening effect that service failure has on repurchase intentions.

\section{The Mediating Role of Negative Emotions}

The importance of emotions on the human experience is crucial in that what we notice and remember, exerting a powerful influence on consumer evaluations (Dolan, 2002). More recent emotion theories emphasize the adaptive value of emotions and the need for emotional regulation in certain circumstances (Gross, 1999; Gyurak et al., 2011). For instance, Kozub et al. (2014) indicate that emotions explain consumers' future behavioral intentions after a service failure. In addition, Varela-Neira et al. (2010) found that emotions play a mediating role in the relationship between cognitive evaluations (i.e., disconfirmation of expectations) and customer satisfaction.

Negative emotions underlie the effects of consumers' appraisals about service failure on post-purchase behaviors, from retaliatory behaviors to conciliatory behaviors (Bonifield and Cole, 2007). The intensity of their negative emotional responses depends on whether the failure leads to functional, monetary, or psychological losses (McColl-Kennedy and Sparks, 2003; Smith et al., 1999). Service failures usually evoke negative emotions (Bonifield and Cole, 2007), leading to consumers' dissatisfaction with service providers (Zeelenberg and Pieters, 2004). Furthermore, poor responses to service failure generate customers' retaliation behaviors through negative word-of-mouth and even switch to other providers (Bonifield and Cole, 2007; Zeelenberg and Pieters, 2004).

Drawing from part-list cueing literature (e.g., Garcia-Marques and Hamilton, 1996; Lindsey and Krishnan, 2007), we argue that sophisticated (vs. modest) service designs work as strong cues for quality that restrict the retrieval of negative information by consumers and 
can minimize the negative impacts of service failure, reducing consumers' negative emotions and increasing repurchase intentions. We propose that when a service failure occurs, sophisticated (vs. modest) service environment designs will reduce consumers' negative emotions because it helps in the reappraisal process after the failure. This consequence might happen because sophisticated environment designs (vs. modest) offer strong quality cues for consumers to "re-construe the service failure encounter with positive meaning, thereby increasing the likelihood to repurchase from the service provider" (Balaji et al., 2017, p. 975). For instance, Pullman and Gross (2004) found that service design elements elicit positive emotional and behavioral responses from consumers. Also, Namkung and Jang (2010) suggested that high-quality cues are critical to evoke positive emotions and generate future favorable behaviors. Thus, we argue that sophisticated service designs stem high-quality cues for consumers, such that when a failure occurs, they will try to protect expectancy-congruent behaviors by undervaluing their negative emotional responses towards the provider, impacting their behavioral intentions. More formally, we hypothesize that:

$\mathbf{H}_{2}$ : Negative emotions mediate the effects of sophisticated (vs. modest) service environment designs on repurchase intentions.

\section{Choice Failure Consequences and Associative Pathways of Retrieval}

Service exchanges differ in complexity, and consumer responses to service failures may vary according to its consequences (Shocker et al., 1991; Swait and Adamowicz, 2001). Research shows that consumers' coping strategies change depending on the consequence of the service failure (i.e., the risk or consequence related to the service choice - Sengupta et al., 2015). For instance, when services have high (vs. low) choice consequences (e.g., choosing a catering service for marriage, or a restaurant for a CEO meeting), consumers often feel more 
stressed (Botti et al., 2009; Kahn and Luce, 2003), generating strong emotional reactions (Kunreuther et al., 2002; Terres et al., 2013). Likewise, service failures with high (vs. low) choice consequences have an important effect on customer outcomes, such as the likelihood of engaging in negative word-of-mouth after the service failure (Weun et al., 2004).

In this research, we propose that choice failure consequences might be an important moderator of service designs (sophisticated vs. modest) effects on repurchase intentions. That is because service environment designs positively influence perceived quality cues (Hooper et al., 2013; Kearney et al., 2013), and may counter the effects of choice failure consequences. We draw on the associative pathways model (Garcia-Marques and Hamilton, 1996; GarciaMarques et al., 2002; Garrido et al., 2012) to show two different retrieval processes that underlie different choice failure consequences (high vs. low). We contend that failures with high choice consequences (e.g., a haircut for a wedding) might trigger a more dense retrieval process via negative emotions, whereas failures with low choice consequences might facilitate the retrieval for expectancy-congruent behaviors (i.e., sophisticated designs and high quality), directly improving consumers' repurchase intentions. We argue that in situations with high choice failure consequences (i.e., greater risk to the consumer), consumers elaborate the retrieval process in a more an exhaustive way (e.g., why did I choose this hairdresser for my wedding?) and a nonselective manner (e.g., do sophisticated hairdressers always produce high-quality haircuts?). Because expectancy-incongruent behaviors are more densely interconnected than are expectancy-congruent behaviors (Garcia-Marques and Hamilton, 1996; Garrido et al., 2012), we anticipate that under high choice failure consequences, there will be greater likelihood of consumers recalling incongruent behaviors (sophisticated service designs and failures), triggering a stronger retrieval process via negative emotions.

However, in situations where the choice failure consequences are low (i.e., lower risk to the consumer), we propose that sophisticated (vs. modest) service environment designs can 
alleviate the negative effects of service failure. We argue that under low choice failure consequences, consumers' retrieval process of service cues is heuristic (not exhaustive) and selective (i.e., based on expectancy-congruency behaviors). This process is heuristic because frequency estimates will be influenced by the ease of retrieval (i.e., based on expectancycongruent behaviors). Since expectancy-congruent behaviors are easier to be retrieved and estimated as more frequent than are incongruent behaviors (Garcia-Marques and Hamilton, 1996), we anticipate that under low choice failure consequences, there will be greater likelihood of consumers recalling congruent behaviors (sophisticated service designs have better quality and lower chances of failures), directly improving consumers' repurchase intentions. Thus, we hypothesize:

H3: Choice failure consequences (high vs. low) moderate the effects of sophisticated (vs. modest) service environment designs on repurchase intentions.

Figure 1 presents our theoretical model and summarizes the hypotheses.

Insert Figure 1 about here

\section{Overview of the Studies}

The present research comprises three experimental studies to test our hypotheses.

Study 1 provides preliminary evidence of the sophisticated service environment designs (sophisticated vs. modest) influence on repurchase intentions after a service failure. Study 2 
explores the mediating role of negative emotions on service environment design effects on repurchase intentions. Study 3 further refines our predictions by exploring how choice failure consequences moderate the influence of sophisticated service environment designs on repurchase intentions. The results, taken together, determine the effects of sophisticated service environment designs in increasing consumers' repurchase intentions and in mitigating consumers' negative reactions to service failures. The set of findings supports the service environment design effect that is consistent with our theoretical account and the moderating role played by choice failure consequences. Appendix A provides a summary of the studies.

\section{Study 1: Service environment designs Effects on Repurchase Intentions after Service}

\section{Failure}

Study 1 examines the effects of service environment designs on consumers' repurchase intentions when a service failure occurs. The objective of Study 1 is to provide a test of our prediction that sophisticated service environment designs will increase repurchase intentions compared to modest service environment designs in a service failure situation $\left(\mathrm{H}_{1}\right)$. We test our prediction by asking consumers to evaluate a movie session failure considering the cinema with sophisticated service environment designs (e.g., upscale cinema) and with modest service environment designs (e.g., simple cinema) in terms of repurchase intentions.

\section{Participants and procedure}

Two hundred U.S. residents $(58.4 \%$ men, mean age $=34.7, \mathrm{SD}=10.9)$ completed the study in Amazon Mechanical Turk. Participants completed the study individually and were unaware of its purpose. One of the main advantages of this online platform is that the 
demographic data on Amazon Mechanical Turk is representative of the U.S. population as traditional subject pools, with gender, race, age and education of samples all matching the population more closely than undergraduate college samples (Paolacci et al., 2010). In our studies using Mturk, we have used a filter on the online panel to get participants from the United States only. We also asked that the participants must be Americans in the studies' instructions, and they confirmed this request by accepting the consenting form (before starting the studies). Besides that, we checked the participants' country information (IP address and self-report). Thus, those who were non-Americans did not participate in the studies. In addition, to avoid nationality perception issues, we included questions, in the demographic information section in the study, regarding the participant's nationality ("country where you were born" and "country of residence"). We only considered participants that informed "USA" in these two questions. Therefore, all participants included in our analysis for studies using online panel samples are Americans according to these verifications (filters, informed consent form, IP address, and self-reported demographic information). Furthermore, to avoid potential issues, we analyzed all data by verifying open-ended questions while checking IPs and duplicate responses. As a cover story, participants received instructions concerning a survey about a service evaluation in a 10-minute session.

Participants were randomly assigned to one of the two experimental conditions that asked them to imagine themselves in a cinema theater to watch a debut movie. The sophisticated (vs. modest) service environment designs described the cinema theater as sophisticated, elegant, and stylish (vs. basic, modest, and humble). Afterward, participants filled three open-boxes by answering how they imagined the cinema theater (ambient factor), the decor (design factor), and the customer service of employees (social factor) (Bitner, 1992). Examples of sophisticated environment design descriptions are: "The theater is spacious," "somewhat art deco," "it is a luxurious, relaxing environment," "very high-quality sound," 
“extremely comfortable seating." Examples of modest environment design descriptions are: "old, not many people, not exciting," "red and burgundy plastic chairs and sofas," "dingy red carpet," "the seats were old made of that tough plastic, and red cloth," "the theater itself was smaller than usual," "chairs squeak with the slightest movement."

After participants described the cinema service environment, for the manipulation of the service failure, they were informed that while watching the movie, in the best scene, the projection stops presenting the movie once the screen goes dark. Participants did not receive information about the reason the service failure occurred. We use cinema as a service context in Study 1 because this is a common service consumed globally.

\section{Measures}

Repurchase intentions were measured in three items $(\alpha=.867)$, according to Magini et al. (2007) and Maxham III (2001). Participants evaluated repurchase intentions with a 7-point Likert scale (1 - do not agree at all; 7 - completely agree). The items evaluated were: "I would choose this service again in the future," "I will choose this service provider another time if I need," and "I'm likely to choose this service in the future."

The manipulation check for the service environment verified participants evaluations across ambient ( $\alpha=.907,4$ items), design $(\alpha=.956,9$ items), and social factors $(\alpha=.928,7$ items) (Baker et al., 2002; Bitner, 1990, 1992; Bojanic and Rosen, 1994; Fu and Parks, 2001; Madanoglu, 2006). Participants rated each item using a 7-point Likert scale (1 - do not agree at all; 7 - completely agree).

\section{Findings}

Manipulation checks. The manipulation check confirmed the service environment manipulation in terms of ambient, design, and social factors. One-way ANOVA results show 
the main effect of service environment designs on the ambient $\left(F_{(1,197)}=48.07, p<.001\right)$, $\operatorname{design}\left(F_{(1,197)}=80.33, p<.001\right)$, and social $\left(F_{(1,197)}=45.97, p<.001\right)$ factors evaluation. Specifically, participants in the sophisticated (vs. modest) service environment designs condition revealed higher averages than those in the modest service environment designs condition in terms of ambient $\left(M_{\text {sophisticated }}=5.7\right.$ vs. $\left.M_{\text {modest }}=4.5\right)$, design $\left(M_{\text {sophisticated }}=5.4\right.$ vs. $=3.8)$, and social $\left(M_{\text {sophisticated }}=5.4\right.$ vs. $\left.M_{\text {modest }}=4.3\right)$ factors.

Repurchase intentions. Results from one-way ANOVA reveal the main effect of service environment designs on consumers' repurchase intentions in a service failure $\left(F_{(1,198)}\right.$ $=5.41, p<.05)$. Specifically, participants in the sophisticated service environment designs condition indicated higher levels of repurchase intentions than those in the modest service environment designs condition $\left(M_{\text {sophisticated }}=4.1\right.$ vs. $\left.M_{\text {modest }}=3.6\right)$, providing support for $\mathrm{H}_{1}$. Figure 2 presents the results of Study 1.

Insert Figure 2 about here

\section{Discussion}

Study 1 suggests that repurchase intentions for a service failure depend on the service environment: sophisticated vs. modest service environment designs. Whereas sophisticated service environment designs elicit higher post-failure repurchase intentions, modest service environment designs present lower levels of convincing consumers to repurchase again, which provides support for our prediction $\left(\mathrm{H}_{1}\right)$. In Study 2, we extend these findings by also testing the mediating role of negative emotions on service environment design effects on repurchase intentions $\left(\mathrm{H}_{2}\right)$. 


\section{Study 2: The Mediating Role of Negative Emotions}

The objective of Study 2 is to test our prediction that negative emotions mediate the effects of service environment designs from service environments on repurchase intentions $\left(\mathrm{H}_{2}\right)$. We test our hypothesis that consumers reduce negative emotions, as a result of a service failure, in a sophisticated than in a modest service environment design that will then enhance repurchase intentions. Study 2 extends Study 1 by providing evidence for service environment design effects using a party as a new service context and a student sample, increasing the generalizability of the findings.

\section{Participants and Procedure}

One hundred and one undergraduate students $(51.5 \%$ men, mean age $=25.53, \mathrm{SD}=$ 8.5) completed the study individually in a major University. According to Paolacci et al. (2010), the benefits of undergraduate samples, compared to online panels, is the reduction of risks of multiple responses, and non-response error. Besides, although undergraduate samples are less representative than online panels, they are a more controlled environment to conduct experiments (for a full comparison, please see Paolacci et al., 2010). As in Study 1, Study 2 is a between-subjects experimental design that examined service environment design effects in two levels (sophisticated vs. modest). Participants were randomly assigned to the experimental conditions and completed the study individually, being unaware of conditions. The cover story stated that the study was about a service evaluation in a 15 -minute session.

Participants were asked to evaluate their experience in relation to a party situation. In this study, we asked participants to describe the service environment related to the party. The 
party description presented information about the service environment design dimensions defined by Bitner (1992) for the ambient factor (i.e., room and noise), design factor (i.e., decor), and social factor (i.e., customer service of employees).

Specifically, we gave participants the following instructions in the sophisticated service environment design condition: "Imagine you decide to go to a party with your friends. The place where the party will take place is sophisticated, comfortable, and very modern. We would like you to describe in detail the ambiance of this party. For example, what would the decoration of this place be? What would the waiters look like? Think about these elements and describe the location of this sophisticated party." Participants in the modest service environment design condition read a similar description, but with a small change regarding the service environment designs: "The place where the party will occur is simple, not very comfortable and a bit older."

After describing the party service environment in an open-box, participants were informed that a service failure occurred during the party. The service failure included in this study was presented as the following: "Imagine you're in the middle of the party when the lighting goes off. The place gets dark, and no one knows what is going on. Someone from the organization informs that the party will be closed due to a problem in the electricity supply, which could not be foreseen."

\section{Measures}

As in Study 1, the dependent variable repurchase intentions was measured across three statements $(\alpha=.887)$ : "I would choose this service again in the future," "I will choose this service another time if I need," and "I'm likely to choose this service in the future." Participants evaluated each statement using a 7-point Likert scale (1 - do not agree at all; 7 - completely agree). 
Negative emotions were included in Study 2 as a mediator variable. Participants evaluated five statements $(\alpha=0.618)$ regarding regret, a common negative emotion associated with service failure, over the party choice (Bonifield and Cole, 2007). Participants rated the statements across a 7-point Likert scale (1 - do not agree at all; 7 completely agree).

We verified the manipulation of the service environment designs by using the same items of Study 1 for ambient ( $\alpha=0.957,4$ items), design $(\alpha=0.970,9$ items), and social factors ( $\alpha=0.906,7$ items) (Baker et al., 2002; Bitner, 1990, 1992; Bojanic and Rosen, 1994; Fu and Parks, 2001; Madanoglu, 2006). Participants evaluated each item using a 7-point Likert scale (1 - do not agree at all; 7 - completely agree).

\section{Findings}

Manipulation checks. The manipulation check verified the service environment designs description in terms of ambient, design, and social factors. Results from one-way ANOVA show that service environment designs has a main effect in consumers evaluations in terms of ambient $\left(F_{(1,101)}=46.07, p<.001\right)$, design $\left(F_{(1,101)}=63.63, p<.001\right)$, and social $\left(F_{(1,101)}=41.58, p<.001\right)$ factors. Results indicate that participants in the sophisticated service environment design condition presented higher averages than those in the modest service environment design condition in terms of the ambient $\left(M_{\text {sophisticated }}=5.9\right.$ vs. $M_{\text {weak }}=$ $4.2)$, design $\left(M_{\text {sophisticated }}=5.8\right.$ vs. $\left.M_{\text {modest }}=3.6\right)$, and social $\left(M_{\text {sophisticated }}=5.8\right.$ vs. $\left.M_{\text {modest }}=4.0\right)$ factors.

Repurchase intentions. Results from one-way ANOVA support the main effect of service environment designs from a service environment on repurchase intentions $\left(F_{(1,101)}=\right.$ $14.41, p<.001)$. Specifically, participants in the sophisticated service environment design condition reported higher levels of repurchase intentions than those in the modest service 
environment design condition $\left(M_{\text {sophisticated }}=4.2\right.$ vs. $\left.M_{\text {modest }}=2.9\right)$, providing additional support for $\mathrm{H}_{1}$.

Negative emotions and repurchase intentions. We analyzed the effects of service environment designs (independent variable) on repurchase intentions (dependent variable) through negative emotions (mediator) (model 4 - Hayes, 2013). The Hayes (2013) macro for SPSS $®$ and 5,000 bootstrapped samples were used to analyze the mediation process. Results reveal the mediation of negative emotions between the relation of service environment designs on repurchase intentions.

The bootstrap analysis shows that the indirect effect of service environment designs on repurchase intentions through negative emotions was significant (indirect effect $(\mathrm{a} \times \mathrm{b})=.26$; 95\% CI: .03 to .59 ), supporting $\mathrm{H}_{2}$. The direct effect of service environment designs on repurchase intentions was also significant (direct effect $[\mathrm{c}]=1.09 ; 95 \% \mathrm{CI}$ : .36 to $1.82, p<$ .05). Thus, the findings suggest that negative emotions mediate the effects of service environment designs on post-failure repurchase intentions and that sophisticated (vs. modest) service environment designs reduce consumers' negative emotions, which in turn enhances repurchase intentions. Figure 3 illustrates the results of Study 2.

Insert Figure 3 here

\section{Discussion}

Study 2 replicates the findings of the service environment design effects on repurchase intentions, as reported in Study 1. Study 2 demonstrates that consumers are more willing to repurchase again from a service provider after a failure if the service was performed in a 
service environment with sophisticated service environment designs, than with modest service environment designs. Study 2 also explains this relation by revealing the mediating role of negative emotions. We find that consumers are more likely to repurchase from a provider with sophisticated (vs. modest) service environment designs, because it helps consumers reduce their negative emotions caused by the failure, which, in turn, will increase repurchase intentions. In Study 3, we extend these findings by testing choice failure consequences as a moderation for service environment design effects.

\section{Study 3: The Moderation of Choice Failure Consequences}

The objective of Study 3 is to provide a test of our prediction that sophisticated (vs. modest) service environment designs have a positive effect on repurchase intentions by reducing negative emotions depending on the choice failure consequences $\left(\mathrm{H}_{3}\right)$. Study 3 extends the previous studies by examining how choice failure consequences and service environment designs interact to influence consumers' repurchase intentions. We observed a nonstudent sample to enhance the validity of the findings. We tested our prediction by analyzing the influence of a failure during a restaurant dinner with high (vs. low) consequences for the consumer.

\section{Participants and Procedure}

One hundred fifty-three U.S. residents (56.9\% male, $\mathrm{M}=31.3, \mathrm{SD}=11.15$ years old) took part in the study in Amazon Mechanical Turk. As per Study 1, all the procedures to the inclusion of participants followed strict guidelines for studies using online panel samples (filters, informed consent form, IP address, and self-reported demographic information). Also, 
to avoid potential issues, we analyzed all data by verifying the questions while checking IPs and duplicate responses. Study 3 examined the interaction effect of choice failure consequences and service environment designs on consumers' repurchase intentions mediated by negative emotions. Study 3 is a 2 (service environment designs: sophisticated vs. modest) x 2 (choice failure consequences: high vs. low) between-subjects experimental design.

In Study 3, we chose a restaurant context because it should be a familiar service context to consumers in general. Participants were randomly assigned to the experimental conditions and completed the study individually, being unaware of conditions. The cover story stated that the study was about a service evaluation in a 15-minutes session. Participants were first assigned to one of the two choice failure consequences manipulation (high vs. low). Choice failure consequences were manipulated by asking participants to imagine themselves going out for dinner with their boss (high choice failure consequences) or alone (low choice failure consequences). In the high choice failure consequences condition, the scenario was as the following: "You are doing very well in your job. Then one day, your boss invites you to dinner and tells you to choose the restaurant on the Internet. You believe that your boss will promote you." In the low choice failure consequences condition, the participants were informed that "they want to eat something different and thus decided to look for restaurant options on the Internet."

After reading the choice failure consequences manipulation, participants were assigned to the service environment design conditions (sophisticated vs. modest). The manipulation of service environment designs informed participants that to find a restaurant option, they have searched for more information on the Internet and found some online reviews presenting descriptions about service environment designs of the chosen restaurant. In the sophisticated (vs. modest) service environment design condition, the online reviewers indicated that the restaurant was sophisticated and elegant (vs. basic and modest), had modern 
(vs. humble) décor and furnishing, was very quiet (vs. little noisy), the waiter was polite (vs. distracted) in explaining details about the dishes, and the staff uniforms were stylish (vs. basic). The online reviews, collectively, described the ambient factor (i.e., noise), design factor (i.e., décor and furnishing), and social factor (i.e., customer service of employees) that according to Bitner (1992) comprise the service environment designs. A 30 minutes delay manipulated the service failure on the dinner order, and the waiter did not apologize for the inconvenience.

\section{Measures}

Repurchase intentions were measured by the same three items $(\alpha=0.955)$ used in previous studies. Participants evaluated the items using a 7-point Likert scale (1 - do not agree at all; 7 - completely agree). As in Study 2, negative emotions were rated in Study 3 as the mediation variable. Negative emotions were measured into the same five $(\alpha=$ 0.843) statements regarding regret over the choice of the restaurant as used in Study 2 (Bonifield and Cole, 2007). Participants rated the statements on a 7-point Likert scale (1 do not agree at all; 7 - completely agree).

To check the service environment designs manipulation, we measured the same items adopted in the earlier studies: ambient ( $\alpha=0.951,4$ items), design $(\alpha=0.983,9$ items), and social $(\alpha=0.970,7$ items). We implemented a 7-point Likert scale (1 - do not agree at all; 7 completely agree) to assess the service environment design items.

In Study 3, we included the general perception of choice failure consequences to check the manipulation. The choice failure consequence was measured across four items $(\alpha=0.955)$ adapted from Moss-Morris et al. (2002). The items evaluated were: "This restaurant choice has important consequences," "This restaurant choice can have significant consequences," "This 
restaurant choice can affect the way people perceive you," and "This restaurant choice has important consequences in your life." Participants assessed the statements using a 7-point Likert scale (1 - do not agree at all; 7 - completely agree).

\section{Findings}

Manipulation checks. As in the previous studies, we used ambient, design, and social factors to check the manipulation of the service environment. Results from one-way ANOVA show that service environment designs had a main effect on participants' evaluation of $\operatorname{ambient}\left(F_{(1,151)}=165.06, p<.001\right), \operatorname{design}\left(F_{(1,151)}=190.68, p<.001\right)$, and social factors $\left(F_{(1,151)}=131.50, p<.001\right)$. Results indicate that participants in the sophisticated service environment design condition declared higher averages than those in the modest service environment design condition in terms of ambient $\left(M_{\text {sophisticated }}=6.1\right.$ vs. $\left.M_{\text {modest }}=3.7\right)$, design $\left(M_{\text {sophisticated }}=6.1\right.$ vs. $\left.M_{\text {modest }}=3.6\right)$, and social factors $\left(M_{\text {sophisticated }}=6.1\right.$ vs. $\left.M_{\text {modest }}=4.0\right)$.

Results from one-way ANOVA indicate that the manipulation of the choice failure consequences had a main effect in relation to participants' general perception $\left(F_{(1,151)}=\right.$ $76.50, p<.001)$. Specifically, results suggest that participants in the high choice failure consequence condition declared higher averages than those in the low choice failure consequence condition $\left(M_{\text {high }}=4.9\right.$ vs. $\left.M_{\text {low }}=2.8\right)$. In general, manipulation checks results demonstrate that the manipulation of service environment designs and choice failure consequences worked as expected.

The Moderating Role of Choice failure consequences. We analyzed the mediation process of service environment designs (independent variable) on consumers' repurchase intentions (dependent variable) through negative emotions (mediator) moderated by choice failure consequences (moderated mediation - model 8 - Hayes, 2013). The Hayes (2013) 
macro for SPSS ${ }^{\circledR}$ and 5,000 bootstrapped samples were used to analyze the mediation process.

The bootstrap analysis shows that the indirect effect of service environment designs and choice failure consequences on repurchase intentions through negative emotions was significant (indirect effect $(\mathrm{a} \times \mathrm{b})=.56$; 95\% CI: .01 to 1.22 ), supporting $\mathrm{H}_{3}$. The results for mediation are presented for each level of choice failure consequences (see Figure 4) to provide a deeper understanding of the mediation process. Specifically, when the failure consequence was low, the indirect effect of service environment designs on repurchase intentions through negative emotions is significant $((\mathrm{ax} b)=.46$; 95\% CI: .11 to .82$)$ and the direct effect is also significant $([\mathrm{c}]=.59, p<.01)$. Thus, the results suggest low failure consequences facilitate the retrieval for expectancy-congruent behaviors, such that service designs directly improve consumers' repurchase intentions (and weakens the effect via negative emotions).

For high choice failure consequences, the mediated effect of negative emotions is stronger and significant $((\mathrm{a} \times \mathrm{b})=1.02 ; 95 \% \mathrm{CI}$ : .56 to 1.58$)$, however the direct effect of service environment on repurchase intentions was not significant $([\mathrm{c}]=.02, \mathrm{~ns})$. Therefore, the results reveal that for consumers under high choice failure consequences, the mediation of negative emotions is stronger, triggering a more dense retrieval process via negative emotions and making the direct effect not significant.

Insert Figure 4 here 


\section{Discussion}

Study 3 extends our previous findings in important ways. Study 3 sheds light on the moderating role of choice failure consequences on the service environment design effects on consumers' repurchase intentions through negative emotions $\left(\mathrm{H}_{3}\right)$. We find that service environment designs can mitigate the negative effects of service failure, mainly if the consequence of the failure was high for the consumers. That is because sophisticated service environment designs are important for consumers in reducing their negative emotions caused by the failure with high consequences that can enhance repurchase intentions. For consumers where the failure consequence is low, the service environment designs can directly influence consumers' decision to repurchase again from the service provider in the future.

\section{General Discussion}

Recently, service providers are raising their attention to failures and, so they are investing more in post-failure strategies (Balaji et al., 2017). We expand previous literature regarding the integrated service system (Santos-Vijande et al., 2013) and the importance of post-failure (Hocutt et al., 1997; Mattila and Wirtz, 2004; Smith, 1999) by demonstrating the importance of sophisticated (vs. modest) service environment designs in increasing repurchase intentions after service failures. This paper contributes to the literature in three main ways.

First, it provides insight into the service environment designs of service environment effects on repurchase intentions. The results go beyond the service environment designs and are an essential cue for service experience (Zeithaml et al., 2011). The findings show that when consumers face a service failure, they are likely to stronger intentions to repurchase again from a service environment with sophisticated cues of quality. The results highlight the 
importance of managing the service environment to increase positive behavioral intentions toward service providers when failures occur. The negative effect of service failures can be attenuated by the presence of a service environment with sophisticated designs. These findings advance research from Bhandari et al. (2007), who argued that consumers form a set of expectations about how they should be treated when a service failure occurs based on past experience. In the case of the present research, we reveal how the sophisticated service environment forms quality cues, driving positive expectations about the service recovery process.

Second, this paper explores the importance of service environment designs from the service environment in relation to the emotional consequences of service failure, a topic rarely investigated (except for Shocker et al., 1991; Swait and Adamowicz, 2001). The findings reveal that sophisticated (vs. modest) service environment designs, and high (vs. low) service failures consequences interact, increasing repurchase intentions mediated by negative emotions. In doing so, this research contributes to the more recent stream of research on service environment designs (Balaji et al., 2017; Choi and Choi, 2014) aimed at uncovering the emotional mechanisms underlying consumer reactions to service failure. Balaji et al. (2017) investigated the emotion regulation of customers through suppression and reappraisal of repurchase intentions using a correlational study (scenario-based survey). We contribute to these authors by showing in three experiments the role of service design cues in helping consumers cope with the failure. In particular, we advance Balaji et al. (2017) by showing that sophisticated (vs. modest) service designs work as strong cues for quality that restrict the retrieval of negative information by consumers and can minimize the negative impacts of service failure, reducing consumers' negative emotions and increasing repurchase intentions. Moreover, we contribute to Choi and Choi's (2014) correlational study that suggests that the emotional responses of customers towards companies are crucial after service failure 
and recovery. We advance those findings showing how service designs underlie the changes in emotional responses from consumers to service failures. Since in sophisticated service designs, customers are more likely to have positive expectations for the recovery of "failed" encounters regulating their emotions through reappraisal, they rebuilt the service failure encounter with positive meaning (Bhandari et al., 2007).

Third, this research broadens the extant understanding of the boundary conditions that affect service failures by introducing a new service environment designs effect conceptualization, which depends on choice failure consequences. In the present study, we extend previous views on how consumers cope with service failures (e.g., Sengupta et al., 2015), uncovering the moderating role of choice failure consequences on service designs cueing effects via associative pathways (Garcia-Marques and Hamilton, 1996; GarciaMarques et al., 2002; Garrido et al., 2012). In particular, we show two different retrieval processes that underlie different choice failure consequences: a more dense retrieval process via negative emotions (high choice consequences) or a facilitated retrieval process for expectancy-congruent behaviors that directly affect repurchase intentions (low choice consequences).

\section{Managerial Implications}

This research fills a gap in the literature regarding the service environment as a strategic element in consumers' response to a service failure, identifying important boundary conditions for managers (choice failure consequences). Managers should be attentive to focus on continuous improvements of their quality cues to mitigate adverse effects of service failures, considering the importance of service environment designs revealed in the present study. For managers of sophisticated designs, it is important that their environment designs 
signal high-quality cues that match the brand's reputation (Forbes, 2018). That is because consumers will look for expectancy-congruent behaviors to recover from a service failure. In our studies, we showed the effects of sophisticated service designs on fine dining and entertainment (cinema for adult consumers or a party for students). Service providers can try to work on the combination these factors of ambient (e.g., temperature, music, odor), design (e.g., architecture, equipment, furnishing), and social (e.g., staff, other customers) (Bitner, 1992) to ensure the retrieval process of quality cues follow congruency expectations from consumers (i.e., sophistication cues usually lead to better quality).

However, for providers of modest service designs, there are at least two insights from our research to improve their responses to service failures. First, since our results suggest that retrieval of quality cues drive positive service failure outcomes, modest service designs might improve service design effects by using explicit cues about quality (Luchs et al., 2010). Second, managers of modest service designs might focus on offering services with low choice consequences (e.g., a regular, but high-quality restaurant), to facilitate the retrieval process for expectancy-congruent behaviors that directly affect repurchase intentions, instead of relying on a retrieval process via negative emotions (high choice consequences).

Finally, the findings also provide an important warning for sophisticated service providers, primarily those offering services with high choice consequences for consumers (e.g., wedding or fine dining). For example, if a customer makes reservations for an important dinner (with high choice consequences) in a restaurant with a sophisticated design and the food is disappointing or delivered late, consumers will engage in a dense retrieval process via negative emotions. Thus, it is important to have outstanding service recovery strategies that match the brand's sophistication reputation. 


\section{Limitations and Future Research}

Besides the theoretical and managerial contributions, this research presents limitations that might stimulate future research. Although scenario-building experimental techniques are widely used, they cannot simulate important service environment design aspects such as odor or temperature that influence service experiences (Mattila and Wirtz, 2001; Morrison et al., 2011; Spangenberg et al., 2005). Thus, future studies could focus on real service environments to holistically capture the effects of service environment designs on post-failure outcomes. Future studies could also explore how the recovery effort effect decreases consumers' negative emotions and increases conciliatory behaviors depending on service environment design.

Besides, in our studies, we collected data from an online survey panel of U.S. residents (Studies 1 and 3) and a sample of undergraduate students (Study 2). Further research could use field data (e.g., data from fine dining restaurants) or run experimental field studies (e.g., conduct the study in a real movie theater), extending the validity of our findings to other samples.

Finally, sophisticated service environment designs can play a role depending on the compensation for service failures offered to consumers. Future studies could test the effects of diverse types of compensation, such as monetary, psychological, or product exchange, and types of failure such as monetary losses, lack of attention, and flawed products (Roschk and Gelbrich, 2014) on sophisticated service designs. Also, further research could explore other post-failure variables besides repurchase intentions, such as word-of-mouth and retaliation behavior, to extend our findings. 


\section{References}

Alba, J. W., \& Chattopadhyay, A. (1985), "Effects of context and part-category cues on recall of competing brands", Journal of Marketing Research, 22(3), 340-349.

Baker, J., Grewal, D., and Parasuraman, A. (1994), "The influence of store environment on quality inferences and store image”, Journal of the Academy of Marketing Science, 22(4), 328-339.

Baksi, A. K. (2017), "Mapping zone of tolerance from destination atmospherics”, AsiaPacific Journal of Innovation in Hospitality and Tourism, 6(2), 1-23.

Balaji M.S., Sanjit Kumar Roy, Ali Quazi, (2017), “Customers’ emotion regulation strategies in service failure encounters", European Journal of Marketing, 51 (5/6), 960-982.

Bambauer-Sachse, S. and Rabeson, L. E. (2014), "Effective Use of Non-monetary and Monetary Compensation in Service Recovery", 2014 AMA Winter Educators' Proceedings, I-33 - I-41.

Barakat, L. L., Ramsey, J. R., Lorenz, M. P., and Gosling, M. (2015), “Severe service failure recovery revisited: Evidence of its determinants in an emerging market context. International Journal of Research in Marketing, 32(1), 113-116.

Berry, L. L., Seiders, K., and Grewal, D. (2002), "Understanding service convenience”, Journal of Marketing, 66(3), 1-17.

Bhandari, M.S., Tsarenko, Y. and Polonsky, M.J. (2007), “A proposed multi-dimensional approach to evaluating service recovery", Journal of Services Marketing, 21(3), 174185.

Bitner, M, J. (1990), "Evaluating service encounters: the effects of service environments and employee responses".." The Journal of Marketing, 69-82. 
Bitner, M, J. (1992), "Servicescapes: The impact of service environments on customers and employees. The Journal of Marketing, 57-71.

Bitner, M, J., and Booms, B. H. (1982), “Trends in travel and tourism marketing: The changing structure of distribution channels ”, Journal of Travel Research, 20(4), 39-44.

Bojanic, D. C., and Rosen, L. D. (1994), "Measuring service quality in restaurants: an application of the SERVQUAL instrument”, Journal of Hospitality and Tourism Research, 18(1), 3-14.

Bonifield, C., and Cole, C. (2007), “Affective responses to service failure: Anger, regret, and retaliatory versus conciliatory responses", Marketing Letters, 18(1-2), 85-99.

Booms, B. H., and Bitner, M”, J. (1982), “Marketing services by managing the environment”, Cornell Hotel and Restaurant Administration Quarterly, 23(1), 35-40.

Botti, S., Orfali, K., and Iyengar, S. S. (2009), “Tragic Choices: Autonomy and emotional responses to medical decisions ”, Journal of Consumer Research, 36(3), 337-352.

Boulding, W., Kalra, A., Staelin, R., \& Zeithaml, V. A. (1993). A dynamic process model of seviceservice quality: from expectations to behavioral intentions. Journal of marketing research, 30(1), 7-27.

Chang, K. C. (2016), "Effect of servicescape on customer behavioral intentions: Moderating roles of service climate and employee engagement", International Journal of Hospitality Management, 53, 116-128.

Choi, B. and Choi, B. (2014), “The effects of perceived service recovery justice on customer affection, loyalty, and word-of-mouth", European Journal of Marketing, 48 (1/2), 2014, 108-131. 
Choi, H., \& Kandampully, J. (2018), “The effect of atmosphere on customer engagement in upscale hotels: An application of SOR paradigm", International Journal of Hospitality Management.

Choi, S., \& Mattila, A. S. (2008), "Perceived controllability and service expectations: Influences on customer reactions following service failure", Journal of Business Research, 61(1), 24-30.

Collier, J. E., Breazeale, M., \& White, A. (2017), “Giving back the "self” in self service: customer preferences in self-service failure recovery", Journal of Services Marketing, 31(6), 604-617.

Dagger, T. S., Danaher, P. J., Sweeney, J. C., and McColl-Kennedy, J. R. (2013), “Selective halo effects arising from improving the interpersonal skills of frontline employees”, Journal of Service Research, 16(4), 488-502.

Davidow, M. (2003), “Organizational responses to customer complaints: What works and what doesn't', Journal of service research, 5(3), 225-250.

Dean, D. H. (2014), "Visual Antecedents of Patronage: Personal and Professional Items in the Servicescape", Services Marketing Quarterly, 35(1), 68-83.

DiPietro, R. B., and Campbell, J. (2014), “The Influence of Servicescape and Local Food Attributes on Pleasure and Revisit Intention in an Upscale-Casual Dining Restaurant”, FIU Hospitality Review, 31(4).

Dolan, R.J. (2002), “Emotion, cognition, and behaviour”, Science, 298, 1191-1194.

Durna, U., Dedeoglu, B. B., and Balikçioglu, S. (2015), “The role of servicescape and image perceptions of customers on behavioral intentions in the hotel industry", International Journal of Contemporary Hospitality Management, 27(7), 1728-1748. 
Ellen, T., and Zhang, R. (2014), "Measuring the effect of company restaurant servicescape on patrons' emotional states and behavioral intentions", Journal of Foodservice Business Research, 17(2), 85-102.

Estelami, H. (2000), “Competitive and procedural determinants of delight and disappointment in consumer complaint outcomes", Journal of Service Research, 2(3), 285-300.

Forbes (2016), "Bad Customer Service Costs Businesses Billions of Dollars”, available at: https://www.forbes.com/sites/shephyken/2016/08/27/bad-customer-service-costsbusinesses-billions-of-dollars/\#516f49a75152 (accessed 15 November 2017).

Forbes (2018), “The 10 Most Customer-Obsessed Companies In 2018,” available at: https://www.forbes.com/sites/blakemorgan/2018/02/15/the-10-most-customer-obsessedcompanies-in-2018 (accessed 15 February 2020).

Fu, Y. Y., and Parks, S. C. (2001), "The relationship between restaurant service quality and consumer loyalty among the elderly ”, Journal of Hospitality and Tourism Research, 25(3), 320-326.

Gabbott, M., Tsarenko, Y. and Mok, W.H. (2011), "Emotional intelligence as a moderator of coping strategies and service outcomes in circumstances of service failure ", Journal of Service Research, 14(2), 234-248.

Garcia-Marques, L., \& Hamilton, D. L. (1996), "Resolving the apparent discrepancy between the incongruency effect and the expectancy-based illusory correlation effect: The TRAP model", Journal of Personality and Social Psychology, 71(5), 845.

Garcia-Marques, L., Hamilton, D. L., \& Maddox, K. B. (2002), "Exhaustive and heuristic retrieval processes in person cognition: Further tests of the TRAP model", Journal of Personality and Social Psychology, 82(2), 193. 
Garrido, M. V., Garcia-Marques, L., \& Hamilton, D. L. (2012), "Hard to recall but easy to judge: Retrieval strategies in social information processing”, Social cognition, 30(1), $56-70$.

Gasparotto, L. S., Pacheco, N. A., Basso, K., Dalla Corte, V. F., Rabello, G. C., \& Gallon, S. (2018), "The role of regulation and financial compensation on trust recovery", Australasian Marketing Journal (AMJ), 26(1), 10-16.

Gelbrich, K., and Roschk, H. (2011), “Do complainants appreciate overcompensation? A meta-analysis on the effect of simple compensation vs. overcompensation on postcomplaint satisfaction", Marketing Letters, 22 (1), 31-47.

Gelbrich, K., Gäthke, J.. and Grégoire, Y. (2015), “How much compensation should a firm offer for a flawed service? An examination of the nonlinear effects of compensation on satisfaction”, Journal of Service Research, 18 (1), 107-123.

Gross, J.J. (1998), “Antecedent-and response-focused emotion regulation: divergent consequences for experience, expression, and physiology", Journal of Personality and Social Psychology, 74(1), 224-237.

Gross, J.J. (1999), “Emotion regulation: past, present, future”, Cognition and Emotion, 13(5), 551-573.

Gross, J.J. and Barrett, L.F. (2011), "Emotion generation and emotion regulation: one or two depends on your point of view", Emotion Review, 3(1), 8-16.

Gross, J.J. and John, O.P. (2003), "Individual differences in two emotion regulation processes: implications for affect, relationships, and well-being”, Journal of Personality and Social Psychology, 85(2), 348-362.

Harrison-Walker, L. J. (2012), “The role of cause and affect in service failure”, Journal of Services Marketing, 26(2), 115-123. 
Harvard Business Review (2016), “The Best Luxury Services Are Customized, Not Standardized," available at: https://hbr.org/2016/03/the-best-luxury-services-arecustomized-not-standardized (accessed 15 February 2020).

Heidenreich, S., Wittkowski, K., Handrich, M., \& Falk, T. (2015), “The dark side of customer co-creation: exploring the consequences of failed co-created services', Journal of the Academy of Marketing Science, 43(3), 279-296.

Hocutt, M. A., Chakraborty, G., and Mowen, J. C. (1997), “The impact of perceived justice on customer satisfaction and intention to complain in a service recovery", NA-Advances in Consumer Research Volume 24, 457-463.

Hooper, D., Coughlan, J., and Mullen, M. R. (2013), “The servicescape as an antecedent to service quality and behavioral intentions”, Journal of Services Marketing, 27(4), 271280.

Jiang, Z., Nagasawa, S. Y., and Watada, J. (2014), "Luxury fashion brand image building: the role of store design in Bally and Tod's Japan”, Management Decision, 52(7), 12881301.

Joireman, J., Grégoire, Y. and Tripp, T.M. (2016), “Customer forgiveness following service failures", Current Opinion in Psychology, 10, 76-82.

Kahn, B. E., and Luce, M. F. (2003), “Understanding high-stakes consumer decisions: mammography adherence following false-alarm test results”, Marketing Science, 22(3), $393-410$.

Kearney, T., Coughlan, J., and Kennedy, A. (2013), “An exploration of the effects of the servicescape on customer and employee responses in a grocery retail context", Irish Journal of Management, 32(2), 71. 
Kim, W. G., \& Moon, Y. J. (2009), “Customers' cognitive, emotional, and actionable response to the servicescape: A test of the moderating effect of the restaurant type", International journal of hospitality management, 28(1), 144-156.

Kotler, P. (1973), “Atmospherics as a marketing tool ”, Journal of Retailing, 49(4), 48-64.

Kozub, K. R., O’Neill, M. A., \& Palmer, A. A. (2014), “Emotional antecedents and outcomes of service recovery", Journal of Services Marketing, 28(3), 233-243.

Kumar, A., and Kim, Y. K. (2014), "The store-as-a-brand strategy: The effect of store environment on customer responses”, Journal of Retailing and Consumer Services, 21(5), 685-695.

Kunreuther, H., Meyer, R., Zeckhauser, R., Slovic, P., Schwartz, B., Schade, C., and Hogarth, R. (2002), "High stakes decision making: Normative, descriptive and prescriptive considerations", Marketing Letters, 13(3), 259-268.

Lindsey, C. D., \& Krishnan, H. S. (2007), "Retrieval disruption in collaborative groups due to brand cues", Journal of Consumer Research, 33(4), 470-478.

Line, N. D., Hanks, L., \& Kim, W. G. (2018), “An expanded servicescape framework as the driver of place attachment and word of mouth", Journal of Hospitality \& Tourism Research, 42(3), 476-499.

Liu, S. Q., Bogicevic, V., \& Mattila, A. S. (2018), “Circular vs. angular servicescape: "Shaping" customer response to a fast service encounter pace", Journal of Business Research, 89, 47-56.

Madanoglu, M. (2006), “Validating restaurant service quality dimensions”, Journal of Foodservice Business Research, 7(4), 127-147. 
Mattila, A. S., and Wirtz, J. (2001), "Congruency of scent and music as a driver of in-store evaluations and behavior”, Journal of Retailing, 77(2), 273-289.

Mattila, A. S., and Wirtz, J. (2004), “Consumer complaining to firms: the determinants of channel choice”, Journal of Services Marketing, 18(2), 147-155.

Maxham, J. G. (2001), “Service recovery's influence on consumer satisfaction, positive wordof-mouth, and purchase intentions ”, Journal of Business Research, 54(1), 11-24.

McColl-Kennedy, J. R., and Sparks, B. A. (2003), “Application of fairness theory to service failures and service recovery", Journal of service research, 5(3), 251-266.

Morrison, M., Gan, S., Dubelaar, C., and Oppewal, H. (2011), "In-store music and aroma influences on shopper behavior and satisfaction”, Journal of Business Research, 64(6), $558-564$.

Moss-Morris, R., Weinman, J., Petrie, K., Horne, R., Cameron, L., and Buick, D. (2002), “The revised illness perception questionnaire (IPQ-R)",)," Psychology and Health, 17(1), 1-16.

Namkung, Y. and Jang, S.C. (2010), "Effects of perceived service fairness on emotions, and behavioural intentions in restaurants ”, European Journal of Marketing, 44(9/10), 1233 1259.

Paolacci, G., Chandler, J., \& Ipeirotis, P. G. (2010), “Running experiments on amazon mechanical turk", Judgment and Decision making, 5(5), 411-419.

Patrício, L., Gustafsson, A., \& Fisk, R. (2018), “Upframing service design and innovation for research impact”, Journal of Service Research, 21(1), 3-16. 
Patterson, P. G., Cowley, E., and Prasongsukarn, K. (2006), “Service failure recovery: the moderating impact of individual-level cultural value orientation on perceptions of justice”, International Journal of Research in Marketing, 23(3), 263-277.

Petzer, D. J., De Meyer, C. F., Svari, S., \& Svensson, G. (2012), “Service receivers' negative emotions in airline and hospital service settings", Journal of Services Marketing, 26(7), 484-496.

Pullman, M. E., \& Gross, M. A. (2004), “Ability of experience design elements to elicit emotions and loyalty behaviors”, Decision sciences, 35(3), 551-578.

Reimer, A., and Kuehn, R. (2005), “The impact of servicescape on quality perception. European Journal of Marketing, 39(7/8), 785-808.

Roschk, H., and Gelbrich, K. (2014), "Identifying appropriate compensation types for service failures a meta-analytic and experimental analysis ”, Journal of Service Research, 17(2), 195-211.

Roschk, H., and Kaiser, S. (2013), “The nature of an apology: An experimental study on how to apologize after a service failure", Marketing Letters, 24(3), 293-309.

Santos-Vijande, M., Ana María Díaz-Martín, Leticia Suárez-Álvarez, Ana Belén del RíoLanza, (2013), “An integrated service recovery system (ISRS): Influence on knowledgeintensive business services performance", European Journal of Marketing, 47 (5/6), 934-963.

Sheng, X., Siguaw, J. A., \& Simpson, P. M. (2016), “Servicescape attributes and consumer well-being”, Journal of Services Marketing, 30(7), 676-685.

Shocker, A. D., Ben-Akiva, M., Boccara, B., and Nedungadi, P. (1991), “Consideration set influences on consumer decision-making and choice: Issues, models, and suggestions. Marketing Letters, 2(3), 181-197. 
Shostack, G. L. (1977), "Breaking free from product marketing. The Journal of Marketing, 41, 73-80.

Smith, A. K., Bolton, R. N., and Wagner, J. (1999), “A model of customer satisfaction with service encounters involving failure and recovery”, Journal of Marketing Research, $36(3), 356-372$.

Spangenberg, E. R., Grohmann, B., and Sprott, D. E. (2005), "It's beginning to smell (and sound) a lot like Christmas: the interactive effects of ambient scent and music in a retail setting”, Journal of Business Research, 58(11), 1583-1589.

Stocchi, L., Wright, M., \& Driesener, C. (2016), "Why familiar brands are sometimes harder to remember", European Journal of Marketing, 50(3/4), 621-638.

Sweeney, J., Sweeney, J., Armstrong, R. W., Armstrong, R. W., Johnson, L. W., and Johnson, L. W. (2016), "The effect of cues on service quality expectations and service selection in a restaurant setting: A retrospective and prospective commentary", Journal of Services Marketing, 30(2), 136-140.

Terres, M. S., and Pizzutti dos Santos, C. (2013), “Consumer trust in high-consequence decisions: a study of medical services", International Journal of Pharmaceutical and Healthcare Marketing, 7(2), 120-141.

Van Vaerenbergh, Y., Varga, D., De Keyser, A., \& Orsingher, C. (2018), “The Service Recovery Journey: Conceptualization, Integration, and Directions for Future Research", Journal of Service Research, 1094670518819852.

Varela-Neira, C., Vázquez-Casielles, R. and Iglesias-Argüelles, V. (2010), "Explaining customer satisfaction with complaint handling”, International Journal of Bank Marketing, 28(2), 88-112. 
Verhoef, P. C., Lemon, K. N., Parasuraman, A., Roggeveen, A., Tsiros, M., and Schlesinger, L. A. (2009), “Customer experience creation: Determinants, dynamics, and management strategies ”, Journal of Retailing, 85(1), 31-41.

Walsh, G., Shiu, E., Hassan, L. M., Michaelidou, N., and Beatty, S. E. (2011), “Emotions, store-environmental cues, store-choice criteria, and marketing outcomes ", Journal of Business Research, 64(7), 737-744.

Westbrook, R. A., and Oliver, R. L. (1991), “The dimensionality of consumption emotion patterns and consumer satisfaction”, Journal of Consumer Research, 18(1), 84-91.

Yen, H. R., Gwinner, K. P., \& Su, W. (2004), “The impact of customer participation and service expectation on Locus attributions following service failure", International Journal of Service Industry Management, 15(1), 7-26.

Zeelenberg, M., and Pieters, R. (2004), "Beyond valence in customer dissatisfaction: A review and new findings on behavioral responses to regret and disappointment in failed services”, Journal of Business Research, 57(4), 445-455.

Zeithaml, V. A., M.J. Bitner, D.D. Gremler, A. Pandit (2011), Services marketing ( $5^{\text {th }}$ ed.), McGraw-Hill Publishing Company Limited.

Zhang, J. H., Walsh, C., and Bonnefon, J. F. (2005), "Between-subject or within-subject measures of regret: Dilemma and solution”, Journal of Experimental Social Psychology, 41(5), 559-566. 


\section{FIGURES}

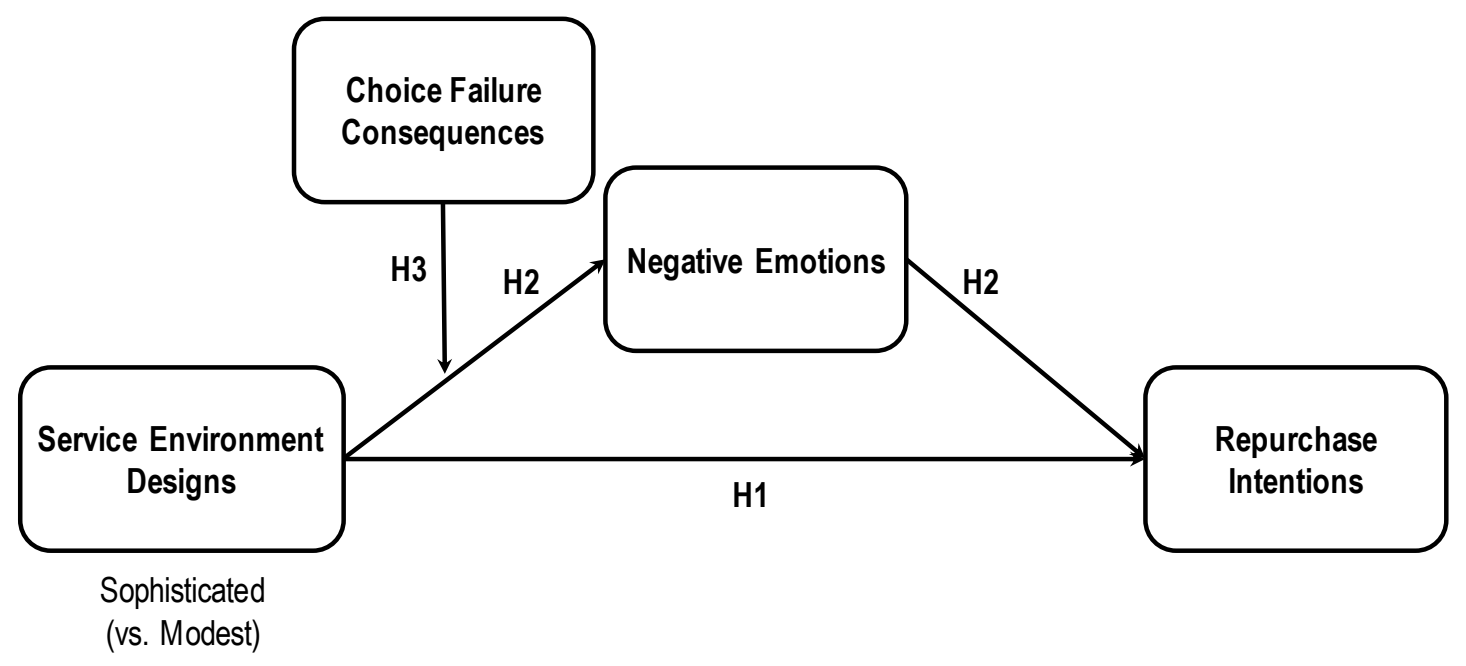

Figure 1: Theoretical Model and Hypotheses 


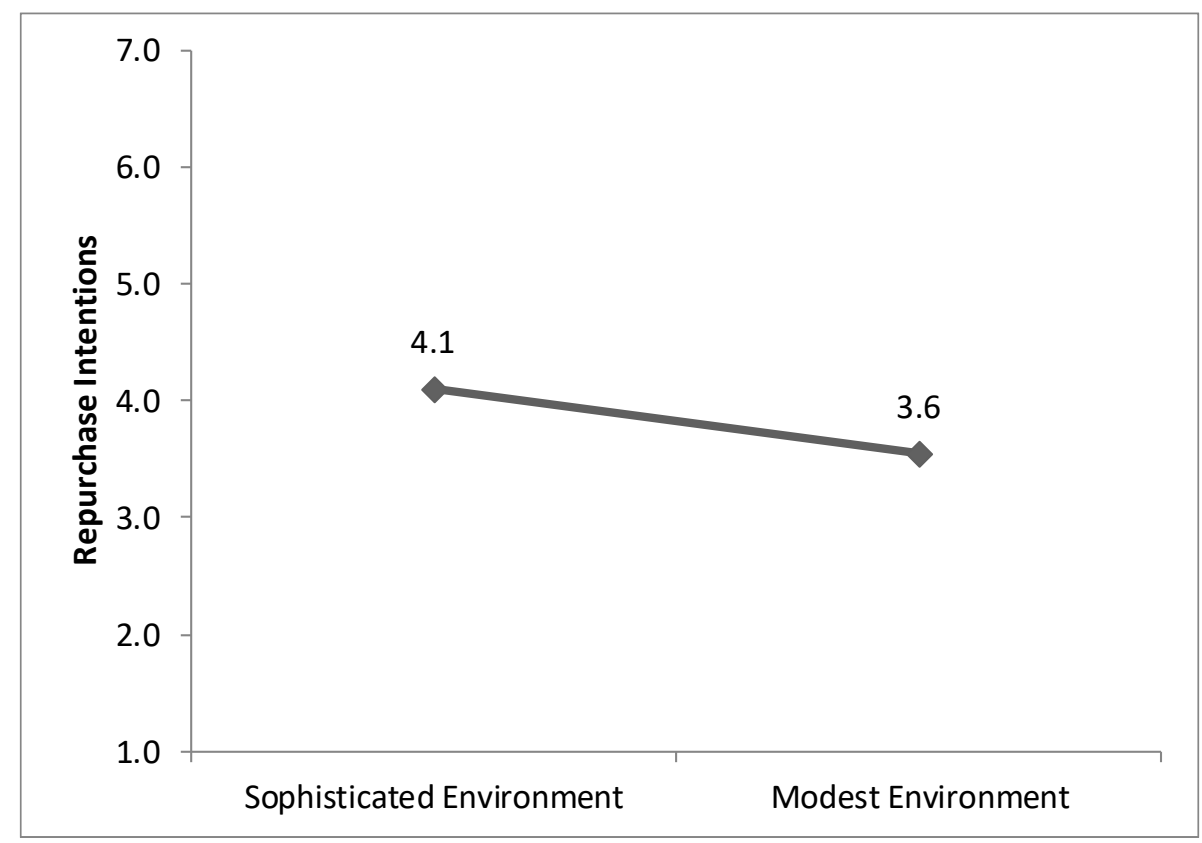

Figure 2: Service Environment Design Effects on Repurchase Intentions in Study 1 


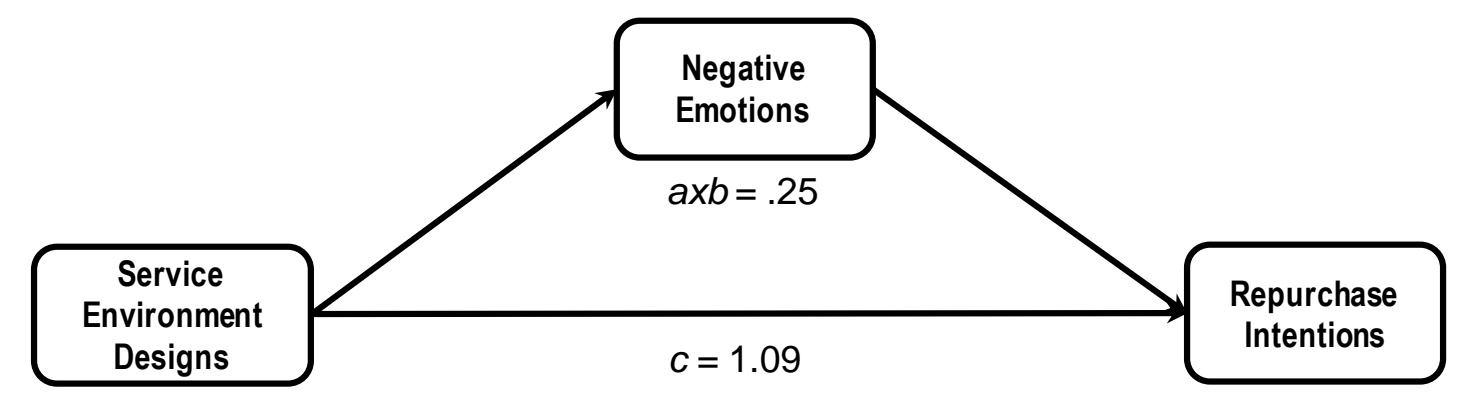

Figure 3: Service Environment Design Effects Mediated by Negative Emotions in Study 2 


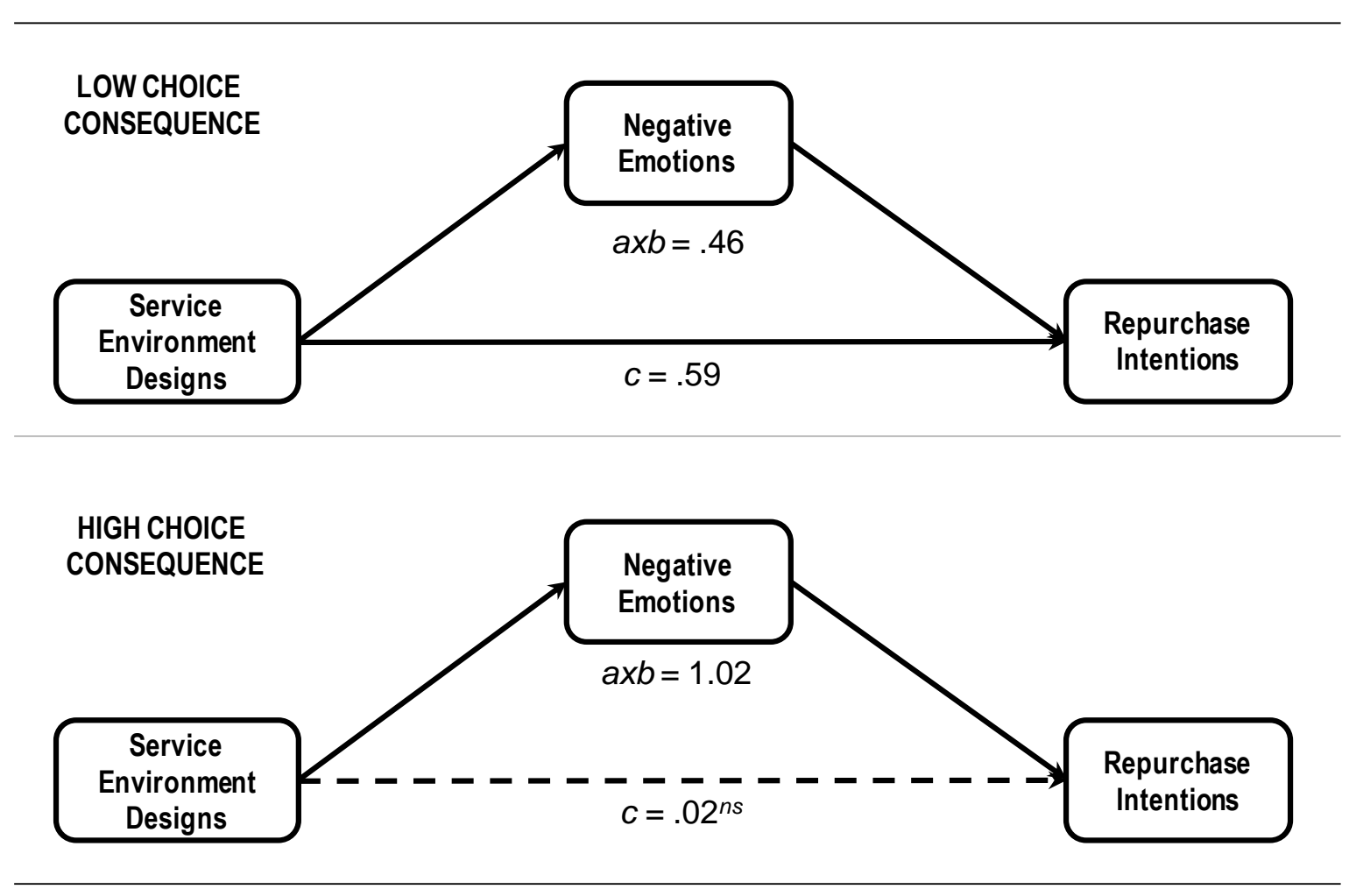

Figure 4: The Moderating Role of Choice Failure Consequences in Study 3 
Appendix A. Summary of the Studies

\begin{tabular}{|c|c|c|c|c|c|c|}
\hline Study & $\begin{array}{l}\text { Sample } \\
\text { Size }\end{array}$ & Participants & Service Environment Designs & $\begin{array}{l}\text { Other } \\
\text { Variables }\end{array}$ & $\begin{array}{l}\text { Dependent } \\
\text { Variables }\end{array}$ & Findings \\
\hline $\begin{array}{l}\text { Study 1: } \\
\text { Cinema } \\
\text { Study }\end{array}$ & $n=200$ & $\begin{array}{l}\text { Online } \\
\text { Experiment } \\
\text { (Amazon } \\
\text { Mturk) }\end{array}$ & $\begin{array}{l}\text { Scenario of a movie session failure } \\
\text { considering a cinema with } \\
\text { sophisticated service environment } \\
\text { designs (e.g., upscale cinema) or with } \\
\text { modest service environment designs } \\
\text { (e.g., simple cinema) }\end{array}$ & $\overline{-}$ & $\begin{array}{l}\text { Repurchase } \\
\text { intentions }(\mathrm{H} 1)\end{array}$ & $\begin{array}{l}\text { Support for H1. Sophisticated (vs. modest) } \\
\text { service environment designs reduce the } \\
\text { dampening effect that service failure has on } \\
\text { repurchase intentions. }\end{array}$ \\
\hline $\begin{array}{l}\text { Study 2: } \\
\text { University } \\
\text { Party Study }\end{array}$ & $n=101$ & $\begin{array}{l}\text { University } \\
\text { students }\end{array}$ & $\begin{array}{l}\text { Participants' description of a party with } \\
\text { their friends as sophisticated, } \\
\text { comfortable, and very modern } \\
\text { (sophisticated service environment } \\
\text { design) or as simple, not very } \\
\text { comfortable and a bit older (modest } \\
\text { service environment design) }\end{array}$ & $\begin{array}{c}\text { Mediation: } \\
\text { Negative } \\
\text { Emotions (H2) }\end{array}$ & $\begin{array}{l}\text { Repurchase } \\
\text { intentions (H1) }\end{array}$ & $\begin{array}{l}\text { Support for H1. Sophisticated (vs. modest) } \\
\text { service environment designs reduce the } \\
\text { dampening effect that service failure has on } \\
\text { repurchase intentions. } \\
\text { Support for H2. Negative emotions } \\
\text { mediate the effects. }\end{array}$ \\
\hline $\begin{array}{l}\text { Study 3: } \\
\text { Restaurant } \\
\text { Study }\end{array}$ & $n=153$ & $\begin{array}{l}\text { Online } \\
\text { Experiment } \\
\text { (Amazon } \\
\text { Mturk) }\end{array}$ & $\begin{array}{l}\text { Scenario where participants searched } \\
\text { for more information on the Internet } \\
\text { and found some online reviews } \\
\text { presenting sophisticated (vs. modest) } \\
\text { descriptions about the service } \\
\text { environment designs of the chosen } \\
\text { restaurant. }\end{array}$ & $\begin{array}{c}\text { Mediation: } \\
\text { Negative } \\
\text { Emotions (H2) } \\
\text { Moderation: } \\
\text { Choice Failure } \\
\text { Consequences } \\
\text { (H3) }\end{array}$ & $\begin{array}{l}\text { Repurchase } \\
\text { intentions (H1) }\end{array}$ & $\begin{array}{l}\text { Support for H1. Sophisticated (vs. modest) } \\
\text { service environment designs reduce the } \\
\text { dampening effect that service failure has on } \\
\text { repurchase intentions. } \\
\text { Support for H2. Negative emotions } \\
\text { mediate the effects. } \\
\text { Support for H3. The effects of } \\
\text { sophisticated service environment designs } \\
\text { on repurchase intentions hold when in high } \\
\text { (vs. low) choice failure consequences. }\end{array}$ \\
\hline
\end{tabular}

